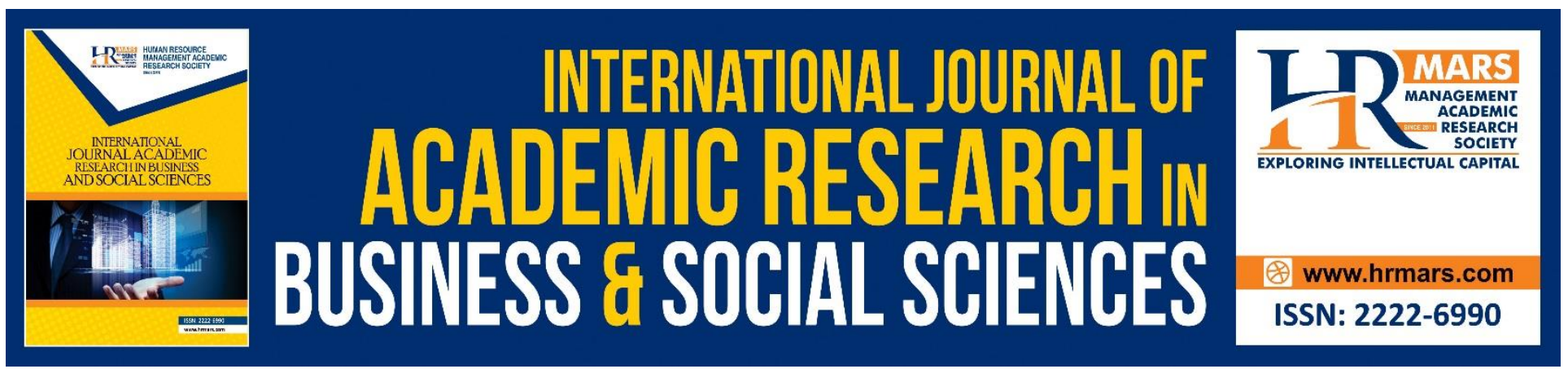

\title{
The Concept of Islamic-Based Management of Construction Project
}

Musmuliadi Kamaruding, Rosni Abdul Rani @ Ibrahim, Intan Syahidah Zulkafa, Wan Nurul Firdaus Wan Mohd Naim

To Link this Article: http://dx.doi.org/10.6007/IJARBSS/v8-i9/4649

DOI: $\quad 10.6007 /$ IJARBSS/v8-i9/4649

Received: 23 August 2018, Revised: 17 September 2018, Accepted: 29 September 2018

Published Online: 15 October 2018

In-Text Citation: (Kamaruding, Ibrahim, Zulkafa, \& Naim, 2018)

To Cite this Article: Kamaruding, M., Ibrahim, R. A. R. @, Zulkafa, I. S., \& Naim, W. N. F. W. M. (2018). The Concept of Islamic-Based Management of Construction Project. International Journal of Academic Research in Business and Social Sciences, 8(9), 705-715.

Copyright: (c) 2018 The Author(s)

Published by Human Resource Management Academic Research Society (www.hrmars.com)

This article is published under the Creative Commons Attribution (CC BY 4.0) license. Anyone may reproduce, distribute, translate and create derivative works of this article (for both commercial and non-commercial purposes), subject to full attribution to the original publication and authors. The full terms of this license may be seen

at: http://creativecommons.org/licences/by/4.0/legalcode

Vol. 8, No. 9, September 2018, Pg. 705 - 715

http://hrmars.com/index.php/pages/detail/IJARBSS

JOURNAL HOMEPAGE

Full Terms \& Conditions of access and use can be found at http://hrmars.com/index.php/pages/detail/publication-ethics 


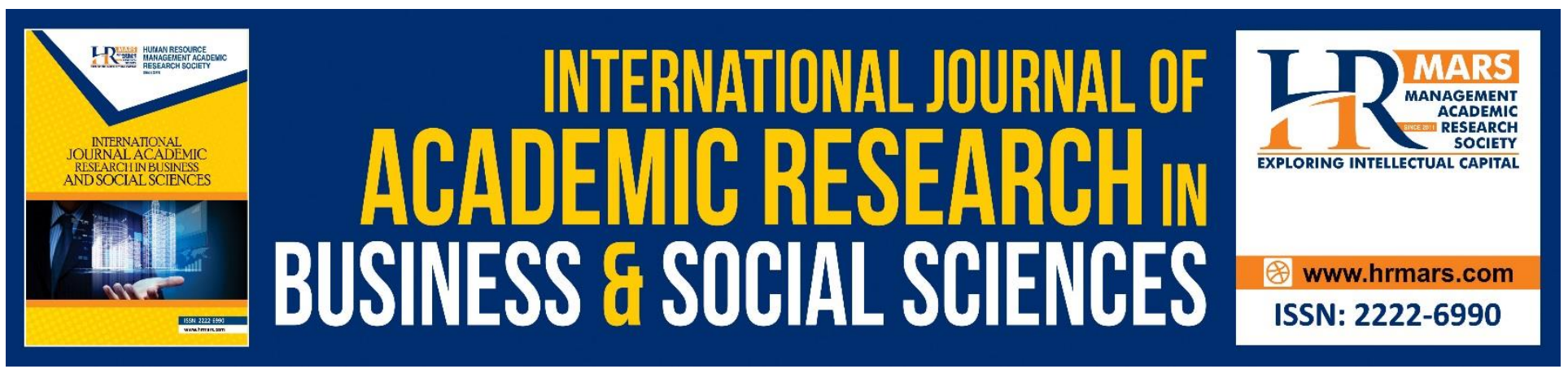

\title{
The Concept of Islamic-Based Management of Construction Project
}

\author{
Musmuliadi Kamaruding \\ School of Advanced and Distance Learning, DRB-HICOM University of Automotive Malaysia, Pekan, \\ Pahang Darul Makmur, Malaysia
}

Rosni Abdul Rani @ Ibrahim

Faculty of Business and Management, DRB-HICOM University of Automotive Malaysia, Pekan,

Pahang Darul Makmur, Malaysia

Intan Syahidah Zulkafa

School of Foundation and Inter Disciplinary Studies, DRB-HICOM University of Automotive

Malaysia, Pekan, Pahang Darul Makmur, Malaysia

\section{Wan Nurul Firdaus Wan Mohd Naim}

School of Foundation and Inter Disciplinary Studies, DRB-HICOM University of Automotive Malaysia, Pekan, Pahang Darul Makmur, Malaysia

\begin{abstract}
The Muslim contractors who involve in the management of construction project should base their work on the Islamic-based management. Any activity that involves Muslims does not become reasonable if they are managed in a non-Islamic manner. In other words, Muslims should practice the management carried out by Prophet Muhammad SAW which is based on the Qur'an and hadith. However, there is still no Islamic-based management of construction project guide discussed in detail. Therefore, in this regard, this study was conducted to identify and analyze the concepts of Islamicbased management of construction project using the document study method and qualitative content analysis method. The result of this study explains the concept of Islamic-based management of construction project is moulded from Islamic tasawur by making Tawhid paradigm as the foundation; emphasizing the principle of the servant and caliph of Allah SWT in the organization; aiming only for the mardhatillah (pleasure of Allah SWT) alone. In conclusion, it is hoped that this study will be a guide for all Muslim contractors in managing their construction projects.
\end{abstract}


INTERNATIONAL JOURNAL OF ACADEMIC RESEARCH IN BUSINESS AND SOCIAL SCIENCES

Vol. 8, No. 9, Sept. 2018, E-ISSN: 2222-6990 (C) 2018 HRMARS

Keywords: Concept, Islamic-Based Management, Construction Project

\section{INTRODUCTION}

The construction industry is growing across the world including Malaysia (Utusan Online, 2017). This growth provides opportunities for the Muslim contractors to participate in the construction industry (Sinar Online, 2012). There is a question of the best concept of management to guide the Muslim contractors in managing their construction projects. What is the appropriate management concept to guide the Muslim contractors in managing their construction projects? Due to this, there are some views that can answer this question.

In Islam, all activities shall be done only for the sake of Allah SWT. At the same time, the ways for carrying out their activity shall also agree with the shariah rules that have been established by Allah SWT (Al-Qaradawi, 1996). Besides that, anything that is related to Islam and involving Muslims would not be equitable if it is managed in a way that is not Islamic (Salleh, 2003). All Muslims must also exercise the management practiced brought by Prophet Muhammad SAW which is based on Qur'an and hadith (Abbasi, Rehman \& Bibi, 2010).

Based on these statements, it can be concluded that the best management concept for the Muslim contractors who involved in the construction project is the Islamic-based management concept. However, based on the literature review, there is still no Islamic-based management of construction project guide discussed in detail. Therefore, in this regard, the study was conducted to identify and analyze the Islamic-based management of construction project that can be used as a guidance by the Muslim contractors. This study uses the document study method and qualitative content analysis method to identify and analyze the concept of Islamic-based management of construction project.

\section{LITERATURE REVIEW}

In this section, the discussion is divided into two categories. The first category is the concept of project management to show the gap between previous studies with this study. The second category is the concept of Islamic-based management which will be used to discuss the concept of Islamicbased management of construction project. The discussion of both categories is as followed.

\section{Project Management System}

The construction industry today applies the project management system in handling the construction project. Generally, project management system refers to the process of planning, organising, monitoring and controlling all aspects of a project and the motivation of all involved to achieve the project objectives safely and within the agreed time, cost and performance criteria (Heagney, 2011; Meredith, Mantel \& Shafer, 2016; Kloppenborg, Anantatmula \& Wells, 2017).

There is previously researcher that discussed in details regarding project management. Among them are Project Management Institute (2008), Heagney (2011), Larson and Gray (2014), Meredith, Mantel and Shafer (2016), Kloppenborg, Anantatmula and Wells (2017). Based on the review, it was found that all these scholars discussed the same thing about project management. The topics discussed are 
project definitions, project management process group, project life cycle, the characteristics of project managers and so on. However, the discussion by Project Management Institute (2008) is more advanced and be a guide to the other scholars. The discussion by Project Management Institute (2008) focused on the project management of body knowledge.

In order to deliver the project successfully, any individual that is involved needs to consider the nine knowledge areas of project management which are: First, project integration management that is utilized to ensure that all elements involved in the project are properly integrated and coordinated especially during the development and execution of the project plan; second, project scope management to ensure that only the works required will be done and completed as agreed by the stakeholders and successfully delivered to them; third, project time management to ensure that the project will be completed on time through the effective scheduling development by clearly identifying the activities, its sequence and duration estimation; fourth, project cost management to ensure that the project will be conducted within the approved budget; fifth, project quality management to ensure that the project achieves the relevant quality standard as required by the stakeholders; sixth, project human resource management to ensure that enhancement of the project management through effective organizational planning, staff acquisition and team development; seventh, project communications management to ensure that the communication planning, distribution of information, reporting of the performance and administrative closure have been done in an effective and efficient way; eighth, project risk management to ensure that the risk management planning have been done through identification of risk and analysis of qualitative and quantitative risk in order to maximize the positive probability or events and minimizing the negative probability which can affect the project objective; and ninth, project procurement management to ensure that the process of acquiring goods and service have been done in an effective and efficient way, and it is able to attain the project scope through procurement planning, solicitation planning and a proper selection of sources (Project Management Institute, 2008).

As a conclusion, the discussion regarding the concept of project management by previously scholars or researchers are still limited as there is still no research found that addressed from an Islamic perspective. Therefore, the next discussion will be focus on Islamic based-management that will use as the basis for discussing the project management from an Islamic perspective to fill the gap.

\section{Islamic-Based Management}

The implementation of the Islamic-based management has emerged since the time of Prophet Muhammad SAW (Mohamed, Ghani \& Basir, 2013). It can be traced back to the era of Nabawi, more than 1400 years ago when Prophet Muhammad SAW established Islam in Medina (Panel YaPEIM Management Academy, 2005). The Islamic-based management was born out of Islamic tasawur by making Tawhid paradigm as the foundation (Salleh, 2009 \& Yusof, 2015). This ideology is derived from the Qur'an and hadith as the main references. Besides that, ijmak and qiyas are also referred as a source of support (Salleh, 2009 \& Yusof, 2015). Further discussion on this is divided into three parts. The first part is the definition of Islamic-based management. The second part is the features of Islamic-based management. The third part is the principles of Islamic-based management. 
INTERNATIONAL JOURNAL OF ACADEMIC RESEARCH IN BUSINESS AND SOCIAL SCIENCES

Vol. 8, No. 9, Sept. 2018, E-ISSN: 2222-6990 @ 2018 HRMARS

\section{Definition of Islamic-based Management}

The Islamic-based management generally refers to the completion of trust by human beings to Allah SWT ie as servants and caliph on earth by doing good deeds and always based on cooperation and meeting in every activity done (Hassan, 1990). Its definitions are also related to the three main components which are human beings, good deeds and community.

Human beings need to perform two main functions namely as a servant of Allah SWT as the caliph of Allah SWT. On the other hand, good deeds refer to the human nature created by Allah SWT to be upright in this world which will help them in the hereafter. Meanwhile, the question about the community also refers to certain places to perform good deeds (Muhamad, Sarwan \& Suyurno, 2008).

Based on the previous definition, it can be deduced that the Islamic-based management actually refers to five criteria. Firstly, it wants to show that the human being created by Allah SWT serves as a servant and also the caliph of Allah SWT. Secondly, the method of management is carried out through cooperation and done by shura that is bounded by shariah, honesty and values, as well as true ethics. Thirdly, it is derived from the Qur'an and hadith as the main sources. Also, ijmak and qiyas act as a source of support. Fourthly, the purpose of this implementation is to create a fair civilization that pleases Allah SWT. Fifthly, the ultimate goal is to get the pleasure of Allah SWT and attain happiness in the world and success in the hereafter (Salleh, 2009).

\section{Islamic-Based Management Features}

The Islamic-based management has its own distinctive features. Among them are the management is based on the Tawhid paradigm; mutual respect and nourishment of justice; having good attitudes; abolition of al-fasad; achieving the ultimate success in the world and the hereafter (Hassan, 1990). Furthermore, the Islamic-based management is also a part of the community system which are: perfecting the workers' physiology; encouraging rewards or wages that are commensurate with trust, duties and responsibilities assigned to the employees; emphasizing the principle of shura in the organization; stressing the spirit of cooperation; practicing the values of humanity and fighting for the truth (Abu Sin, 1991).

Apart from the features previously mentioned, there are other features of the Islamic-based management. It is bounded by the religious laws when making decisions such as halal, haram (forbidden), sunat (encouraged), wajib (compulsory), makruh (not encouraged) and includes siyasah syariah which describes the concept of good and bad based on revelation. It adopts a timely, dynamic and flexible ethics in work culture and focuses on the personal development and human morality. The Islamic-based management is not only comprehensive, taking into account the social, economic, political, cultural and value system within a society, but also integrates human development through the growth of intellect, physical, spiritual and emotion (Omar, 1996).

\section{Islamic Principles of Management}

Among the principles of the Islamic-based management are: the principle of shura which is the principle that encourages the discussion before making a decision; the principle of amal jama'i (good 
deeds) that emphasizes the team spirit in the organization; and the principle of leadership that describes the values and responsibilities of the leaders and followers in the organization (Panel YaPEIM Management Academy, 2005).

In addition, the Islamic-based management also highlights principles such as the principle of alUbudiyah which devotes themselves to Allah SWT; al-Adalah which means to always be fair; alHurriyah which means to give freedom to members of the organization to speak; Al-Musawah which emphasizes similarities among members of the organization; al-Mas'uliyah which is always responsible with the given trust; al-Itqan which refers to performing the task excellently; as well as the principle of $a t-T a$ 'ah (obedient) that is always to obey the leader's instructions as long as it does not conflict with Islam (Muhammad, Sarwan \& Suyurno, 2008).

\section{Research Methodology}

This study is a qualitative study derived from existing documents as suggested by Lebar (2015). According to Lebar (2015), researchers that conducting a qualitative study can use the data from existing documents in the development of theory and research in local and global contexts. This is because, the data from the document can contribute to the process of early conceptualization and data collection. The documents are derived from journals, articles, webs, books, and theses (Bailey, 1984 \& Creswell, 2003). However, the data for this study is limited to documents that only discuss the basic of project management and the features of Islamic-Based management only. After that, the data collected will be analyzed using qualitative content analysis methods. This is because qualitative studies are highly desirable to be analyzed using qualitative content analysis methods (Neuendorf, 2002 \& Schreier, 2012). In addition, the qualitative content analysis method is also a research method that produces a conclusion that makes the data more systematic and organized by identifying specific features of a particular subject (Weber, 1990; Burnard, 1996; Elo \& Kyngas, 2008).

\section{Result and Discussion}

Based on the literature review, the concept of project management that guides the management of construction project has no features of Islamic-based management. For example, there is no emphasis on the Islamic tasawur as a reference, Tawhid as the foundation, the principle of servant and the caliph of Allah SWT, and its goal is more towards the worldly affairs only. Hence, this section will discuss the concept of Islamic-based management as its findings.

In general, the Islamic-based management of construction project refers to a management which is born out of the Islamic tasawur with Tawhid as the foundation. In the meantime, the management methods used to manage the construction projects are always based on the Qur'an and hadith as the primary sources of references, ijmak and qiyas as a source of support. Furthermore, those who are involved in managing the construction project are required to maintain their status as the servant and caliph of Allah SWT on earth. They should uphold good relationship with Allah SWT, fellow human beings and natural resources which is in line with the ultimate goal which is merely to gain the pleasure of Allah SWT. 
To discuss more about the concept of Islamic-based management of project construction, the discussion is divided into three categories. Firstly, Islamic tasawur moulds the management of construction project. Secondly, the emphasis on the servant principle and the caliph of Allah SWT in the organization. Thirdly, the ultimate goal is purely to achieve the mardhatillah which is the pleasure of Allah SWT alone. These three categories are concluded based on the discussion on the Islamicbased management in the literature review section.

\section{Islamic Tasawur as a Construction Project Management Mould}

Tasawur Islam provides an overview of the life settings that make the Tawhid paradigm as the key element. It has a positive effect on all management activities that are carried out by humans both within the organization and outside the organization (Al-Mawdudi, 1985). The Tawhid paradigm refers to the claim that Allah is the Lord of the universe and Almighty over all beings on this earth. It also refers Allah SWT as the only God that is worthy to be worshipped (Ahmad, 1980 \& Al-Faruqi, 1982).

As a Muslim, they have to refer to the Islamic tasawur by making Tawhid as a compass in its organization. This is because, through the reference, there are eight positive effects that can be achieved (Wan Omar, 1996). First, it can produce an open-minded, trustworthy, competent and disciplined individual. Second, it can produce a high self-esteem individual. Third, it can produce a person who is humble (tawaduk). Fourth, it can produce a righteous, brave and truthful individual. Fifth, it can produce an individual who does not easily give up when there is a disaster or failure. Sixth, it can produce an individual with a high degree of patience, determination and importance. Seventh, it can create a person who is calm, subdued, unselfish, not greedy and envious. Eighth, it can produce individuals who obey the rules and laws that have been set by Allah SWT.

\section{The Principle of Servant and Caliph Allah SWT}

The principle of servant and caliph in the Islamic-based management of construction projects explains that all members of the organization (Muslim contractor) have two main functions on this earth namely as a servant of Allah SWT and secondly, as the Caliph of Allah SWT. The further description of the function is as followed.

\section{Muslim contractor as Servant of Allah SWT}

The function of the Muslim contractor as a servant of Allah SWT is clearly stated in the word of Allah SWT which means: "And I did not create the jinn and mankind except to worship Me" (Adh-Dhariyat, 51:56).

As a servant of Allah SWT, the Muslim contractors need to sustain good relationship with Allah SWT during the implementation of construction project management activities. They should also implement the pillars of faith, the pillars of Islam and the teachings of Islam in full, in which to always avoid dishonesty and immorality, and strive to increase the taqwa to Allah SWT while maintaining a relationship based on the relationship as the servants of Allah SWT (Kamri, 2007). 
At the same time, as a servant of Allah SWT, a Muslim contractor should ensure that the activities carried out in the management of construction project are always anticipated as worship. To ensure that the activities performed are considered as worship, the Muslim contractors must meet five conditions (Salleh, 2003). Firstly, intentions should be sincerely because of Allah SWT. Secondly, what is done is not against the Islamic law. Thirdly, the activity to be implemented is in accordance with the Islamic law. Fourthly, the results are not contradictory to the shariah. Fifthly, the basic worship is not left behind.

\section{Muslim contractor as Caliph of Allah SWT}

The Muslim contractor as the caliph of Allah SWT is stated in the word of Allah SWT which means: "And [mention, O Muhammad], when your Lord said to the angels, "Indeed, I will make upon the earth a successive authority." They said, "Will You place upon it one who causes corruption therein and sheds blood, while we declare Your praise and sanctify You?" Allah said, "Indeed, I know that which you do not know" (Al-Baqarah, 2:30).

As the caliph of Allah SWT, the Muslim contractors must always maintain good relationships with their members and their natural resources. They need to show good examples to their organization members such as being courteous, polite and give consideration to wages and welfare to their organizational members with compassion (Panel YaPEIM Management Academy, 2005). In the meantime, the Muslim contractors should always take care of the natural resources during the implementation of construction project management activities. They cannot have a negative impact on the natural resources during their construction projects. For example, air pollution, water pollution and destruction of plant and animal habitats (Salleh, 2003).

\section{Mardhatillah: The Ultimate Goal of Construction Project Management}

The Muslim contractors who are involved in the construction project should set a final goal which is to only get mardhatillah i.e. the pleasure of Allah SWT instead of profit or image enhancement of the organization. The profit or enhancement of the organization's image is the ultimate goal of conventional management of worldly nature. The ultimate goal of getting the pleasure of Allah SWT covers the success and happiness of the world and the hereafter (Salleh, 2003 \& Ahmad, 2013).

In addition, the goal of getting the pleasure of Allah SWT can also augment the spiritual aspect to a person through the increase of faith and the sense of modesty, the practice of shariah and morals. Not only that, if the construction project management activities do not bring any profit in the form of material as expected, they will still earn a reward that leads to profits in the worlds beyond (Ahmad, 2013).

\section{Conclusion}

In conclusion, this study discussed the concept of Islamic-based management of construction project that can be a guidance to all construction project managers especially to the Muslim. At the same time, this study also can fill the gap from the previously studies. The concept of Islamic-based management of construction project that discussed in this study actually want to emphasized three 
things. First, all individuals especially Muslim that involved in managing construction project must base on the Islamic tasawur as a reference to the Tawhid paradigm in its management. Second, they are also need to emphasizes the principle of the servant and caliph of Allah SWT. And third, they also need to setting out to achieve the pleasure of Allah SWT as the ultimate goal in their management of construction project. It is hoped that this study could be utilised as a guideline for all Muslim contractors to ensure that the management they are instigating is always rewarded and coherent with the rules set by Allah SWT.

\section{Acknowledgement}

This article is part of the research entitled "The Contemporary Project Management System: A Study from Various Perspectives" (November 1, 2017-31 October 2018) funded by the Internal Research Grant Scheme, DRB-HICOM University of Automotive Malaysia [IRGS / 012017/010].

\section{Corresponding Author}

Musmuliadi Kamaruding

School of Advanced and Distance Learning

DRB-HICOM University of Automotive Malaysia

26607 Pekan, Pahang Darul Makmur

Malaysia.

Email: musmuliadi@dhu.edu.my

\section{References}

Abbasi, A. S., Rehman, K. U., Bibi, A. (2010). Islamic Management Model. African Journal of Business Management, 4 (9), 1873-1882. Standard: 1993-8233, Impact Factor: 1.105.

Abu Sin, A. I. (1997). Pengurusan dalam Islam. (Terj. Abd Rashid Ngah \& Jusoh Kadir). Kuala Lumpur: Dewan Bahasa dan Pustaka.

Ahmad, F. A. (2013). Konsep pengurusan institusi pembangunan berteraskan Islam. Kuala Lumpur: Dewan Bahasa dan Pustaka.

Ahmad, K. (1980). Economic development in Islamic framework, dlm. Khurshid Ahmad (ed.), Studies in Islamic economics, (pp.177-188). Jeddah: International Centre for Research in Islamic Economics, King Abdul Aziz University.

Al-Faruqi, I. (1982) Tawhid: Its implications for thought and life. Kuala Lumpur: IIIT.

Al-Mawdudi, A. A. (1985). Cara hidup Islam. (Terj. Wan Salim Muhammad Nur). Shah Alam, Selangor: Dewan Pustaka Fajar Sdn Bhd.

Al-Qaradawi, Y. (1996). Memahami keutamaan berasaskan al-Qur'an dan al-sunnah. Petaling Jaya: Angkatan Belia Islam Malaysia (ABIM).

Bailey, K. D. (1984). Kaedah penyelidikan sosial. (Terj. Hashim Awang). Kuala Lumpur: Dewan Bahasa dan Pustaka.

Burnard, P. (1996). Teaching the analysis of textual data: An experiential approach. Nurse Education Today 16, 278-281.

Creswell, J.W. (2014). Research design: Qualitative, quantitative and mixed methods approaches. Sage Publication Ltd. 
INTERNATIONAL JOURNAL OF ACADEMIC RESEARCH IN BUSINESS AND SOCIAL SCIENCES Vol. 8, No. 9, Sept. 2018, E-ISSN: 2222-6990 @ 2018 HRMARS

Hassan, M. A. (1990). Pendekatan tauhid dalam pengurusan dan pentadbiran awam: Konsep, prinsip dan model alternatif dlm. Shafie Mohd Salleh \& Mohd Affandi Hassan (eds.) Kecemerlangan pentadbiran: Dasar dan amalan dalam Islam (pp.26). Kuala Lumpur: Institut Tadbiran Awam Negara.

Heagney, J. (2012). Fundamental of Project Management, $4^{\text {th }}$ Edition. American Management Association.

Kamri, N. A. (2007). Pelaksanaan kod etika Islam di institusi pembangunan berteraskan Islam: kajian kes di Lembaga Tabung Haji Malaysia. Tesis doktor falsafah yang tidak diterbitkan. Universiti Sains Malaysia.

Kloppenborg, T. J., Anantatmula, V. \& Wells, K. N. (2017). Contemporary Project Management, $4^{\text {th }}$ Edition. Cengage Learning.

Larson, E. W. \& Gray, C. F. (2014). Project Management: The Managerial Process, Sixth Edition. McGraw-Hill Education.

Lebar, O. (2015). Penyelidikan Kualitatif. Pengenalan Kepada Teori dan Metode. Perak: Penerbit Universiti Sultan Idris, Tanjong Malim.

Meredith, J. R., Mantel, S. J. M., \& Shafer, S. M. (2016). Project Management: A Managerial Approach. Ninth Edition. John Wiley \& Sons (Asia) Pte Ltd.

Mohamed, H. A.; Ghani, A. M. A; \& Basir, S. A. (2013). The guidance of moral values towards the consolidation of the quality management system according to the Islamic perspective. International Journal of Business and Social Science 4 (4), 254.

Muhamad, R., Sarwan, M. Y \& Suyurno, S. S. (2008). Pengurusan Islam: Teori dan praktis. Pusat Penerbitan Universiti (UPENA), UITM.

Neuendorf, K.A. (2002). The content analysis guidebook. California, US: Sage Publications.

Panel YaPEIM Management Academy (2005). Pengurusan dalam Islam menghayati prinsip dan nilai qurani. Kuala Lumpur: Akademi Pengurusan YaPEIM.

Project Management Institute (2008). A Guide to the project management body of knowledge. PMI.

Salleh, M. S. (2003). 7 prinsip pembangunan berteraskan Islam. Kuala Lumpur: Zebra Editors Sdn Bhd dan Pulau Pinang: Projek Pengurusan Pembangunan Islam, Pusat Pengajian Sains Kemasyarakatan, Universiti Sains Malaysia.

Salleh, M. S. (2009). Ke arah pengurusan pembangunan Islam, dlm. Muhammad Syukri Salleh \& Fadzila Azni Ahmad, (eds.) Pengurusan pembangunan Islam: Prosiding seminar. Pulau Pinang: Universiti Sains Malaysia Pulau Pinang.

Schreier, M. (2012). Qualitative content analysis in practice. London: Sage Publications Ltd.

Sinar Online (2012). Persatuan kontraktor beri bumiputera lebih ruang sertai projek Johor. Accessed on 1/8/2017 from http://www.sinarharian.com.my/persatuan-kontraktor-beri-bumiputeralebih-ruang-sertai-projek-johor-1.84407

Utusan Online (2017). Sektor pembinaan dijangka berkembang 8 peratus. Accessed on 1/8/2017 from http://www.utusan.com.my/bisnes/ekonomi/sektor-pembinaan-dijangka-berkembang8-peratus-1.468272

Omar, W. L. O. (1996). Pengurusan Islam abad ke-21: Revolusi pengurusan untuk keunggulan sektor awam dan korporat. Kuala Lumpur: Utusan Publications and Distributor.

Weber, R.P. (1990). Basic content analysis. Newburry Park, CA: SAGE Publication Ltd. 
INTERNATIONAL JOURNAL OF ACADEMIC RESEARCH IN BUSINESS AND SOCIAL SCIENCES

Vol. 8, No. 9, Sept. 2018, E-ISSN: 2222-6990 @ 2018 HRMARS

Yusof, A. A. (2015). Penilaian prestasi dari perspektif Islam. Kuala Lumpur: Dewan Bahasa \& Pustaka. 